\title{
Inventory of the fruit fly species (Diptera: Tephritidae) linked to the mango tree in Mali, and tests of integrated control
}

\author{
Jean-François VAYSSIÈRES $^{a *}$, Fatogoma SANOGO ${ }^{b}$, Moussa NousSOUROU $^{c}$
}

a Cirad, UPR production fruitière, IITA, Biological Control Center for Africa, 08 BP 0932, Tripostal, Cotonou, Bénin

j.vayssieres@cgiar.org

b IER, CRA de Sikasso, BP 16, Sikasso, Mali

${ }^{\mathrm{C}}$ IER, CRA de Baguineda, BP 30, Bamako, Mali

\footnotetext{
${ }^{*}$ Correspondence and reprints ** Translation of the original article published in Fruits, 2004 vol. 59 , pp. 3-16.
}

\section{Received 7 April 2003}

Accepted 15 September 2003

Fruits, 2007, vol. 62, p. 329-341 (C) 2007 Cirad/EDP Sciences All rights reserved DOI: $10.1051 /$ fruits:2007029 www.fruits-journal.org

RESUMEN EsPAÑoL, p. 341

\section{Inventory of the fruit fly species (Diptera: Tephritidae) linked to the mango tree in Mali and tests of integrated control.}

Abstract - Introduction. In Mali, mango annual production is estimated at $100000 \mathrm{t}$. Because of structural and plant sanitary problems mainly related to the actions of fruit fly, seldom more than $1 \%$ of this production is exported. The principal aim of this study was to develop an integrated control of the Tephritidae using spot treatments. One of the preconditions was to identify the species responsible for the damage in the three principal Mali production zones (Sikasso, Bougouni and Bamako). Materials and methods. Mangos belonging to the principal exported varieties were collected from the beginning of April up to the beginning of October 2000 and were observed to identify the Tephritidae species present in the fruits. The installation of sex attractant or of foodstuff attractant traps allowed us to follow the evolution and constitution of the fruit fly population in the orchards of the three selected sites. The effectiveness of a spot treatment to control Ceratitis sp. was tested. Results and discussion. Starting from adult observations and determination, six species of Tephritidae were identified. Among them, Ceratitis cosyra (Walker), C. quinaria (Bezzi) and C. silvestrii Bezzi were earliest and are thus most prejudicial. C. cosyra represented $86 \%$ of the total recovered flies. The species C. anonae, C. quinaria, C. fasciventris and C. ditissima were identified for the first time in Mali. The damage due to Tephritidae in the middle of the harvest period bordered on $50 \%$ of the crop for the varieties Kent and Keitt and exceeded 60\% for that of Brooks. The 180 traps installed on the three studied sites allowed us to capture 128998 Tephritidae adults belonging to thirteen species; the six species linked to the mango tree represented $99 \%$ of this total. The spot treatments carried out on the three experimental sites gave encouraging results, with a reduction in damage of approximately $50 \%$ in the treated orchards compared with the control orchards. Conclusions. To prolong the action undertaken, it will be interesting to confirm and look for further results obtained during the years to come. The installation of a regional project for controlling mango tree Tephritidae in West Africa would be fundamental in the medium term to limit such an insect pest which itself prevails on the sub-region scale.

Mali / Mangifera indica / Tephritidae / Ceratitis / identification / damage / integrated control / traps / population dynamics

Inventaire des espèces de mouches des fruits (Diptera : Tephritidae) inféodées au manguier au Mali et essais de lutte raisonnée.

Résumé - Introduction. Au Mali, la production annuelle de mangues est estimée à 100000 t. Du fait de problèmes structurels et phytosanitaires principalement liés à l'action des mouches des fruits, rarement plus de $1 \%$ de cette production est exporté. L'objectif principal de cette étude a été de mettre au point une lutte raisonnée contre les Tephritidae du manguier au Mali à l'aide de traitements par taches. L'un des préalables a été d'identifier les espèces responsables des dégâts dans les trois zones principales de production (Sikasso, Bougouni, Bamako). Matériel et méthodes. Des mangues appartenant aux principales variétés exportées ont été collectées de début avril à début octobre 2000 et mises en observation afin d'identifier les espèces de Tephritidae présentes dans les fruits. La pose de pièges à attractifs sexuels ou alimentaires a permis de suivre l'évolution et la constitution des populations de mouches des fruits dans les vergers des trois sites choisis. L'efficacité d'une méthode de traitement par taches pour lutter contre les cératites a été testée. Résultats et discussion. À partir des observations et de la détermination des adultes, six espèces de Tephritidae ont été mises en évidence. Parmi elles, Ceratitis cosyra (Walker), C. quinaria (Bezzi) et C. silvestrii Bezzi ont été les plus précoces et sont donc les plus préjudiciables. C. cosyra a représenté $86 \%$ de l'effectif total des mouches. Les espèces C. anonae, C. quinaria, C. fasciventris et C. ditissima ont été identifiées pour la première fois au Mali. Les dégâts dus aux Tephritidae en milieu de campagne ont avoisiné $50 \%$ de la production des variétés Kent et Keitt et dépassé $60 \%$ de celle de Brooks. Les 180 pièges mis en place sur les trois sites suivis ont permis de capturer 128998 Tephritidae adultes appartenant à treize espèces ; les six espèces inféodées au manguier ont représenté $99 \%$ de cet effectif. Les traitements par taches effectués sur les trois sites expérimentaux ont donné des résultats encourageants, avec une réduction des dégâts d'environ $50 \%$ sur les parcelles traitées par rapport aux parcelles témoins. Conclusions. Pour prolonger l'action entreprise, il sera intéressant de confirmer et d'approfondir les résultats obtenus au cours des années à venir. La mise en place d'un projet régional de lutte contre les Tephritidae du manguier pour l'Afrique de l'Ouest serait fondamentale à moyen terme pour lutter contre de tels ravageurs qui sévissent à l'échelle de la sous-région.

Mali / Mangifera indica / Tephritidae / Ceratitis / identification / dégât / lutte intégrée / piège / dynamique des populations 


\section{Introduction}

Mali's annual mango production [Mangifera indica L. (Anacardiaceae)] is estimated at $100,000 \mathrm{t}$, of which seldom more than $1 \%$ is exported because of structural and plant sanitary problems, mainly due to fruit flies, damage from which is evaluated at approximately $50 \%$ of production.

These flies belong to the Tephritidae family and the genus Ceratitis, which is one of the main groups of pest insects of fruit trees cultivated in tropical Africa. The genus Ceratitis MacLeay comprises approximately 90 species divided into six sub-genera: $\mathrm{Cer}$ atalaspis Hancock, Ceratitis MacLeay, Pardalaspis Bezzi, Pterandrus Bezzi, Acropteromma Bezzi and Hoplolophomyia Bezzi.

There are few publications on inventories and control of African Tephritidae, and more especially of the West African species linked to the mango tree. The only known works at present were conducted in the Northern Côte d'Ivoire [1, 2], Mali [3] and in Guinea [4, 5].

The economy of Mali still relies heavily on the agropastoral sector, which constitutes $43 \%$ of the Gross Domestic Product, GDP [6]. This sector represents approximately $70 \%$ of the value of exports, and provides revenue to $80 \%$ of the population.

In the last three years, the growth in GDP of this country has been achieved through the primary sector, and more particularly food agricultural production (meal and rice) and industrial agricultural production (cotton). The potential irrigable land area for agricultural production has been estimated at 2.2 Mha, distributed around the two main river systems, the Niger-Bani and Senegal [6]. So the areas occupied by food crops and their production volumes have over the past three seasons highlighted the full importance of this sector to the Mali economy. But the growth of the sector remains low because it still essentially relies on increasing the land area cultivated, rather than increasing crop productivity. The fruit and vegetables industry has been revitalised: Mali exports mangos and green beans to Europe, and potatoes and shallots to neighbouring countries.
In Mali, the main mango production zones are around the cities of Sikasso, Bougouni and Bamako. In this third region, a survey by Aprofa (Agency for the promotion of the agricultural industries) [7] evaluated the surface area of mango orchards at 21,953 ha, which makes over 2 million individuals. Furthermore, this tree occupies $28.38 \%$ of cultivated land in Sikasso, 27.83\% in Bougouni, 20.20\% in Yanfolila, 12.64\% in Koutiala, $9.05 \%$ in Kadiolo, $1.14 \%$ in Kolondieba and $0.76 \%$ in Yoroso.

Three sites representative of the agroecological diversity of mango production zones in Mali were adopted for our study: Waibera (Sikasso zone), Madina (Bougouni zone) and Konyini (Bamako zone). In these regions, the harvesting system of $M$. indica is picking, which requires relatively little investment in terms of working hours or input. The greatest damage is always caused by Ceratitis, whether in the southern mango orchards with their Sudanian climate (Bougouni and Sikasso zones) or in the orchards with a more Sahelian climate (Bamako zone).

To optimise control of the mango tree pests and improve the quality of mangos produced, we attempted to draw up an inventory of the Tephritidae species responsible for fruit damage in Mali. We then tested a tracking and alert system to monitor fly population fluctuations, tracked the evolution in the percentage of fruit attacks and conducted spot treatment tests on foliage.

\section{Materials and methods}

\subsection{Choice of trial sites}

The choice of trial sites was made on the following criteria:

- the orchards had to have over 75\% medium-late or late exportable varieties (Kent or Keitt), with the varieties fully identified;

- they had to have a minimum area of 10 ha;

- their trees had to be regularly spaced and have a uniform planting date; 
- the planter also had to agree not to apply any chemical treatments to their orchard or even to the immediate vicinity.

Based on these criteria, and after several weeks of visits and investigations, three sites were selected: Waibera ( $\left.11^{\circ} 11^{\prime} \mathrm{N}, 5^{\circ} 32^{\prime} \mathrm{W}\right)$ near Sikasso, Madina ( $11^{\circ} 20^{\prime} \mathrm{N}, 7^{\circ} 39^{\prime} \mathrm{W}$ ) near Bougouni and Konyini $\left(12^{\circ} 38^{\prime} \mathrm{N}, 7^{\circ}\right.$ 50' W) near Bamako.

\subsection{Inventory of Tephritidae linked to the mango tree}

Mango samples were taken from the three trial sites selected from mid-April 2000, and throughout the 2000 harvest season. In the laboratory, the fruits collected were weighed, counted and classified by variety, date and sample site. After being allocated a sequence number, they were placed for observation onto mesh supports mounted on basins filled with wet sand, in which larvae emerging from the fruits could drop and metamorphose into pupae. For each variety, the batches were individualised according to the site and their sampling date for easy referencing of the sample origin.

The collected larvae were raised in a big outdoor insectarium. Once a week the sand covering the bottom of the containers was washed and then sieved to collect the pupae which had formed during the week. The pupae, collected with flexible tweezers, were then put with a sequence number into small hatchery boxes lined with moist blotting paper. The hatchings were checked up on every 3 days to collect the adults, which were then identified using a binocular magnifier. For difficult to determine cases, the insects were prepared on straw or polypore to show up certain differentiating morphological criteria.

We made the identifications ourselves, with certain species verified by De Meyer of the Royal Museum of Central Africa in Tervuren, Belgium.

\subsection{Setting the traps}

At the start of the season, sixty traps in total were installed at each of the three selected trial sites. They were set after the mango- harvesting peak of the precocious Amélie variety, but before the harvest of the later Kent and Keitt varieties.

The traps were hung from a primary branch of the lower third of the leafing, at a medium distance from the centre of the tree. The traps had to not be directly exposed to sunlight, and they had to have clear access. The branch supporting the trap had been coated previously with solid grease in order to prevent any predatory activity of ants (Oecophylla) on the dead Tephritidae adults caught in the trap. Counts were made every week and traps were rotated clockwise after each emptying.

Two types of trap were required to capture flies of both sexes, with the males mainly attracted by parapheromones, and the females by protein-based liquids. Therefore, the 60 traps installed on each site were divided into 36 dry traps containing sex attractants (parapheromones) and 24 liquid traps containing foodstuff attractants (protein hydrolysate-based). It should be noted that sexually immature males seeking protein sustenance were captured in the protein hydrolysate traps.

The dry sex attractant traps comprised 12terpinyl acetate traps, 12 trimedlure traps, 6 methyl eugenol traps and 6 cuelure traps. The liquid foodstuff attractant traps were divided into 12 buminal and water traps, and 12 buminal, water and borax traps.

The average density was 6 parapheromone traps per hectare, i.e., a distance of approximately $40 \mathrm{~m}$ between traps, to prevent any interaction between the attractants, and 12 foodstuff attractant traps per hectare, with a distance of approximately $20 \mathrm{~m}$ between the traps.

For each trap type, there were four repetitions represented by 4 blocks of 9 dry traps for the sex attractants, and 4 blocks of 6 liquid traps for the foodstuff attractants.

\subsection{Tracking the attack percentage}

At each of the three control plots in the sites monitored, 30 fruits were sampled per week, per tree and per variety. These samples were taken from four commercially cultivated varieties - Kent, Keitt, Brooks and 
Figure 1.

Breakdown of the six species of Ceratitis (Tephritidae) emerging from 1226 mangos collected in mango orchards in Mali during the 2000 season.

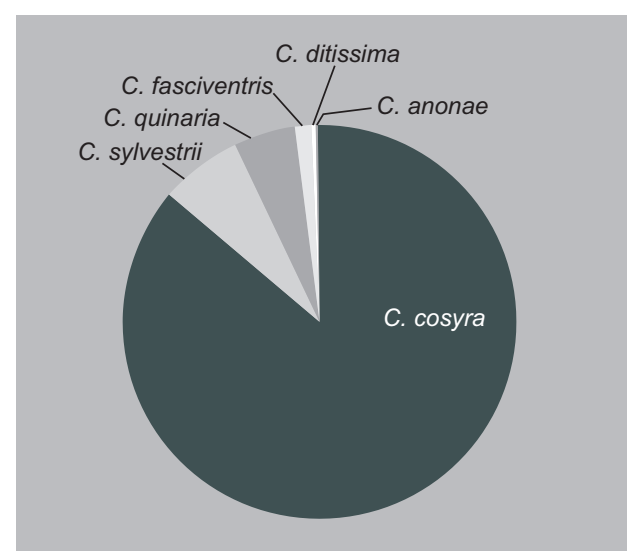

Haden - with 10 trees selected at random per week, per site and per variety. So the trial covered 300 fruits observed per week, per site and per variety. All the fruits underwent a visual check; holed fruits were eliminated, and dubious fruits were dissected.

\subsection{Spot treatment}

One of the objectives of our study was to establish an effective fruit fly control method accessible to producers and preventing risks of mango pollution by residue of active materials. Using a method of this sort will enable the most numerous and damaging populations of fruit fly species to be kept under an economically damaging threshold. However, in Mali, no particular research had yet been conducted to determine this intervention threshold. Since our study began at the start of the season, meaning we could not specify a threshold more accurately, we adopted that used in mango orchards on the island of Reunion, i.e., 25 flies collected per trap and per week $[8,9]$.

Spot treatment, unlike generalised treatment, consists of partially treating the foliage with a spray comprising a mixture of insecticide and a foodstuff attractant. The insects are attracted by the attractant and killed by the insecticide. The mixture was sprayed onto parts of the tree not bearing fruits, to prevent the presence of insecticide residue in the fruits, while limiting the quantities of insecticide spread.

For our trials, spot treatments were applied to the three orchards in the same way, using a Matabi superAgro 16-1 manual sprayer which was used to deliver a spray containing, for $10 \mathrm{~L}$ of water, $100 \mathrm{~mL}$ of Sumithion L-50 (Sumitomo Chemical Cpy Japan, $500 \mathrm{~g} \cdot \mathrm{L}^{-1}$ of insecticide active material) and $200 \mathrm{~mL}$ of $75 \%$ protein hydrolysate (Agrisense BCS, Pontypridd, UK; foodstuff attractant).

All the rows in a given plot were treated, but we chose to apply the spray to one in every two trees in the rows. Only the foliage was treated, over a surface area of approximately $1 \mathrm{~m}^{2}$, at head height and until the spray started running off.

The treatments were applied in series on 28 June, 5 and 12 July, and 6 and 13 September.

\section{Results and discussion}

\subsection{Inventory of Tephritidae linked to the mango tree}

A total of 1226 sampled fruits was collected from 15 orchards visited during the 6 months of the study. These 1226 fruits were attributed to 15 varieties: Keitt, Kent, Brooks, Amélie, Smith, Palmer, Haden, Miami Late, Zill, Julie, Edwards, Alfonse de Goa, Davis Haden, Eldon and Bewerly, by order of yield size. Dissection of the fruits collected yielded 13171 Tephritidae pupae of six species: Ceratitis cosyra (Walker) or the mango fly, represented by $85.58 \%$ of adults obtained, C. silvestrii Bezzi (7.28\%), C. quinaria (Bezzi) (4.89\%), C. fasciventris De Meyer (1.80\%), C. ditissima (Munro) $(0.24 \%)$ and $C$. anonae Graham (0.21\%) (figure 1).

Some of these species had already been reported, $C$. cosyra and $C$. silvestrii in Mali [3], and C. cosyra, C. fasciventris and C. anonae in Guinea [5].

\subsubsection{Inventory of species by geographic zone}

In the Sikasso zone (Waibera site), 652 fruits were harvested, from which 8168 Tephritidae pupae were captured. In this zone, C. cosyra, C. silvestrii and C. quinaria were the most precocious species. The latter two species appear to be the species linked to 
the dry zones (De Meyer, pers. comm.), and it is hardly surprising to see them growing here at the end of the dry season. According to De Meyer, this is the first mention of C. quinaria in West Africa, with the other mentions of this species originating in Botswana, Namibia and South Africa.

In the Bougouni zone (Madina site), 388 fruits were harvested and 2622 Tephritidae pupae were captured. C. cosyra was still largely predominant, followed by C. fasciventris with nearly $7 \%$ of the population. The latter species was described very recently [10]. It becomes a genuinely big factor during the wet season.

In the Bamako zone (Konyini site), 186 fruits were harvested and 2381 Tephritidae pupae were captured. The species $C$ cosyra was also largely predominant here, followed by C. fasciventris.

\subsubsection{Inventory of species by variety}

The percentage of different Tephritidae species was established for each of the main mango export varieties encountered (table I). The late varieties such as Keitt host Tephritidae species present at the end of the season (C.fasciventris, C.anonae and C. ditissima). On the other hand, a late-season variety such as Kent can host Tephritidae species which are active when the precocious varieties (Irwin, Eldon, Amélie, etc.) start ripening. The Brooks and Smith varieties proved the most attractive for the Tephritidae, which we had already observed in Kankan in Guinea [4]. This high attraction was highlighted by the ratio of number of pupae collected to the mass of sampled fruits. This number was in total three times greater for both these varieties than for Amélie, Kent or Keitt (table I), and the damage inflicted more serious.

We note that the fruit sampling only began in mid-April 2000, and it is possible that particularly precocious species could not be detected then. Observation of the fruits harvested from mid-February to midApril would make it possible to verify this fact. In this context, special attention could be paid to the small mangos which drop through natural thinning in February, and which take on a yellow-orange colour. Indeed, in Guinea, in the Kankan zone, dissection of certain fruits which dropped early revealed the presence of one or two C. cosyra larvae [4]. This possibility of the first fruits formed at the very start of the production cycle acting as a host would enable the pest to multiply before the start of the season itself. If this point was also verified in Mali, the intervention dates to be recommended in orchards would have to take into account this possibility of early development. Furthermore, better knowledge of the ecological niches of the three precocious species shown by our study (C. cosyra, C. silvestrii and C. quinaria) would make it possible to suggest more efficient techniques for trapping, monitoring and for control of the Tephritidae.

Furthermore, many wild fruits support the large-scale multiplication of fly populations and facilitate the survival of residual populations outside the mango fruit-ripening period, during the dry season. It would be interesting to study wild fruit samples as part of the implementation of a control strategy.

Table I.

Percentage of the various species of the genus Ceratitis (Tephritidae) emerging from the mangos collected from the orchards in southern Mali, and number of pupae counted per kg of fruit.

\begin{tabular}{|c|c|c|c|c|c|c|c|}
\hline \multirow{2}{*}{$\begin{array}{l}\text { Variety } \\
\text { studied }\end{array}$} & \multicolumn{6}{|c|}{ Species of Ceratitis identified (\%) } & \multirow{2}{*}{$\begin{array}{c}\text { Number of pupae } \\
\text { per kg }\end{array}$} \\
\hline & C. cosyra & C. silvestrii & C. quinaria & C. fasciventris & C. anonae & C. ditissima & \\
\hline Amélie & 83.2 & 12.4 & 4.4 & - & - & - & 15 \\
\hline Kent & 57.3 & 22.4 & 19.2 & 0.7 & 0.4 & - & 18 \\
\hline Keitt & 93.4 & 1.1 & - & 4.2 & 0.4 & 0.8 & 16 \\
\hline Brooks & 81.2 & 11 & 6.7 & 1.1 & - & - & 45 \\
\hline Smith & 98.5 & 1.2 & - & 0.3 & - & - & 57 \\
\hline
\end{tabular}




\subsubsection{Economic importance of the Tephritidae species}

\subsubsection{Ceratitis cosyra}

The species C. cosyra is a major mango pest in Africa; it is present in South Africa, Kenya, Malawi, Mozambique, Sudan, Tanzania, Zaire, Zambia, Zimbabwe [11], Cameroon [12], Madagascar [13], Côte d'Ivoire [1, 2], Guinea [5] and probably in many other West African countries. It also attacks the guava (Psidium guajava), bergamot (Citrus aurantium), avocado (Persea americana) and wild custard apple trees (Annona senegalensis), and many other cultivated or wild fruit trees [11, 14, 15]. It has also been reported in Mali [3] on cultivated fruit trees such as the mandarin (Citrus reticulata) and orange trees (Citrus sinensis), and on wild fruit trees, such as the shea (Vitellaria paradoxa), African peach tree (Sarcocephalus latifolius) and a liana (Landolphia senegalensis). So it is a formidable pest in terms of the multiplicity of its host plants, wild and cultivated, in terms of its wide geographic distribution on the African continent and in terms of its precocity, since it can be found at the very start of the season in Mali [3], as in Guinea [5], or Côte d'Ivoire [16] and more widely in West Africa.

\subsubsection{Ceratitis silvestrii}

The species $C$. silvestrii is found in Nigeria and Senegal [17]. It appears to live on wild fruit trees such as Chrysobalanus sp. and Vitellaria paradoxa [15]. So the mango tree appears to be a host not yet reported. C. silvestrii is a major pest, since this precocious species, with over $7 \%$ of the population counted during our study, occupied the second position after C. cosyra. Collecting holed fruits in February-March could help specify its ecological niche in relation to that of C. cosyra.

\subsubsection{Ceratitis quinaria}

The species $C$. quinaria has been reported in South Africa, Botswana, Malawi, Namibia, Sudan and Zimbabwe, where it is widespread [11]. It is a potential cultivated or wild fruit tree pest [11] in the dry African savannahs. So our observations identified it for the first time on mango trees, and also for the first time in West Africa (De Meyer, pers. comm.). As for C. silvestrii, a study of the presence of species in February-March, and across several regions of Mali, would help to define the range of host plants and their phenology, while specifying the exact impact of their infestations on the mango tree. C. quinaria, C. silvestrii and C. cosyra are major mango pests since their populations are considerable and they attack commercially grown varieties (Amélie and Zill) at the start of the season.

\subsubsection{Ceratitis fasciventris}

The species $C$. fasciventris is considered by De Meyer [10] as a species in its own right, distinct from $C$. rosa. This latter species is apparently widespread from South Africa to Kenya, while $C$. fasciventris is apparently present in West, Central and East African countries (as far as Kenya). The individuals observed in Mali are considered to be atypical from the specimens of $C$. fasciventris from Central and East Africa (De Meyer, pers. comm.) due to darker hair colour on their middle tibias. The species C. rosa is a major pest for around fifty cultivated or wild fruit trees, including the mango, in Africa [11] and in the Mascarene islands, particularly on Reunion [18]. In Mali, C. fasciventris only emerged from holed fruits under observation from June onwards, and especially in July-August. The trapping results complemented these observations.

\subsubsection{Ceratitis anonae}

In Africa, the species C. anonae is a major pest for around ten cultivated or wild fruit trees [11], among which is the mango. It only really appeared on holed fruits under observation from June onwards, especially in July, and in relatively low numbers. It seems to appear a little later than C. fasciventris. Its actual economic repercussions in Mali are difficult to determine exactly. The species seems to be of greater significance as a mango pest in the wetter Sudanian zones Guinea, for example - than in the Sahelian zones [5].

\subsubsection{Ceratitis ditissima}

Like $C$. anonae, the species $C$. ditissima also appears to be of secondary importance for 
the mango, at least in Mali. Its distribution on the African continent is not known precisely, especially since it is possible that this species has been confused with a similar species, C. punctata [3].

\subsection{Inventory of parasitoids}

Larvo-pupal parasitoids obtained primarily from $C$. cosyra and also, to a lesser extent, from C. silvestrii, C. quinaria and C. fasciventris were identified as:

- Psyttalia perproximus (Silvestri) (Braconidae, Opiinae);

- P. cosyrae (Wilkinson) (Braconidae, Opiinae);

- Fopius caudatus (Szépligeti) (Braconidae, Opiinae);

- Diachasmimorpha fullawayi (Silvestri) (Braconidae, Opiinae);

- Tetrastichus giffardianus Silvestri (Eulophidae, Tetrastichinae);

- Spalangia simplex Perkins (Pteromalidae, Pteromalinae);

- Pachycrepoideus vindemmiae (Rondani) (Pteromalidae, Pteromalinae).

This inventory may appear large in view of the abundance of the fly populations, but factors regulating the relations between hosts and parasitoids are in fact very little known. To supplement the action of natural control agents, it would seem necessary, initially, to study their interrelations.

Moreover, three other species of parasitoids emerged from boxes containing Tephritidae and Drosophilidae pupae:

- Leptopilina victoriae Nordlander (Figitidae, Eucoilinae);

- Leptopilina aff. fimbriata (Kieffer) (Figitidae, Eucoilinae);

- Asobara sp. (Braconidae, Alysiinae).

These latter three species are probably linked to the pupae of Drosophilidae diptera (Wharton, pers. comm.).

\subsection{Trap analysis}

\subsubsection{Capture totals for the three sites}

The trapping system implemented enabled us to capture the fly species present in holed mangos and to reveal the most effective attractants for the target pests.

For each species, the captures were added up during the 17 consecutive weeks of trapping (table II). The 180 traps used

\section{Table II.}

Tephritidae capture totals by trapping in mango orchards at three trial sites, in Mali, over 17 weeks of the 2000 season.

\begin{tabular}{|c|c|c|c|c|c|c|c|c|}
\hline \multirow[t]{2}{*}{ Species observed } & \multicolumn{2}{|c|}{ Waibera (Sikasso) } & \multicolumn{2}{|c|}{ Madina (Bougouni) } & \multicolumn{2}{|c|}{ Konyini (Bamako) } & \multicolumn{2}{|c|}{ Total captures } \\
\hline & Population & $\%$ & Population & $\%$ & Population & $\%$ & Population & $\%$ \\
\hline Ceratitis cosyra & 24131 & 93.94 & 54224 & 90.82 & 41921 & 96.14 & 120276 & 93.24 \\
\hline Ceratitis silvestrii & 697 & 2.71 & 317 & 0.53 & 623 & 1.43 & 1637 & 1.27 \\
\hline Ceratitis quinaria & 186 & 0.72 & 133 & 0.22 & 25 & 0.06 & 344 & 0.27 \\
\hline Ceratitis fasciventris & 399 & 1.55 & 4232 & 7.09 & 74 & 0.17 & 4705 & 3.65 \\
\hline Ceratitis anonae & 24 & 0.09 & 244 & 0.41 & 3 & 0.01 & 271 & 0.21 \\
\hline Ceratitis capitata & 14 & 0.05 & 11 & 0.02 & 6 & 0.01 & 31 & 0.02 \\
\hline Ceratitis ditissima & 4 & 0.02 & 37 & 0.06 & 0 & 0.00 & 41 & 0.03 \\
\hline Ceratitis bremii & 59 & 0.23 & 97 & 0.16 & 106 & 0.24 & 262 & 0.20 \\
\hline Bactrocera cucurbitae & 4 & 0.02 & 190 & 0.32 & 840 & 1.93 & 1034 & 0.80 \\
\hline Dacus ciliatus & 7 & 0.03 & 10 & 0.02 & 1 & 0.00 & 18 & 0.01 \\
\hline Dacus punctatifrons & 121 & 0.47 & 47 & 0.08 & 1 & 0.00 & 169 & 0.13 \\
\hline Dacus bivittatus & 36 & 0.14 & 149 & 0.25 & 5 & 0.01 & 190 & 0.15 \\
\hline Dacus vertebratus & 5 & 0.02 & 15 & 0.03 & 0 & 0.00 & 20 & 0.02 \\
\hline Total number of captures & 25687 & 100 & 59706 & 100 & 43605 & 100 & 128998 & 100 \\
\hline
\end{tabular}


allowed us to capture an amount of 128998 Tephritid adults distributed in 13 species. The six fly species linked to the mango represented nearly $99 \%$ of this population. Of these, C. cosyra was predominant in the three sites, with $93 \%$ of the population. C. silvestrii was observed in the second position in Sikasso and in Bamako, and $C$. fasciventris was also found in the second position in Bougouni.

Ceratitis capitata was recovered from citrus fruits collected in Mali: it was also obtained from mangos in Guinea, as well as C. bremii, but in low numbers [5]. C. capitata larvae also live on pimentos and peppers (Solanaceae) throughout West Africa and on Reunion [20].

Bactrocera cucurbitae, Dacus ciliatus, $D$. punctatifrons, D. bivittatus and D. vertebrates are Tephritidae of the Dacini tribe, which are pests of primary hosts belonging to the family Cucurbitaceae. Nevertheless, our colleagues in Korhogo (Côte d'Ivoire) appear to have obtained some specimens of $D$. bivittatus from mangos [2]. Furthermore, it is the first report of B. cucurbitae in Mali. This species is a formidable Cucurbitaceae pest in Asia, in the Pacific, on Reunion [20] and in East Africa [11].

It should be noted that any study tracking the fluctuations of insect populations - and Tephritidae are no exception to the rule must be conducted over several consecutive years before being validated. Therefore, it will be desirable to continue this fruit flycapturing project on mangos in Mali over several years to confirm the initial results obtained.

\subsubsection{Species captured by attractant type}

\subsubsection{Trimedlure}

Trimedlure is a parapheromone which primarily attracts C. rosa, C. fasciventris, C. capitata and C. anonae males. Although this attractant was able to capture some C. cosyra males in Madina, this remained an exception. In spite of a few captures of C. fasciventris with terpinyl, trimedlure without doubt remains the best attractant for this species. Therefore, of a sample of
650 adult $C$. fasciventris captured with this attractant in Madina, 99\% were male.

\subsubsection{Terpinyl acetate}

Terpinyl acetate is a relatively effective and versatile sexual attractant for C. cosyra, C. silvestrii, C. quinaria, C. fasciventris, C. anonae and even C. ditissima. It is the only attractant capable of capturing males of the three fly species observed early in Mali: C. cosyra, C. silvestrii and C. quinaria. Terpinyl acetate was also able to capture female C. fasciventris. Indeed, of a sample of 550 adults captured with this attractant in Madina, 23\% were females and 77\% males.

\subsubsection{Methyl eugenol}

Methyl eugenol is a parapheromone primarily effective for certain species of the genus Bactrocera and rare species of Ceratitis. It was the only attractant capable of capturing males of $C$. bremii; it also attracts a few males of $C$. fasciventris.

\subsubsection{Cuelure}

Cuelure, a parapheromone primarily effective for the genus Dacus and a few species of Bactrocera, captured males of D. punctatifrons, D. bivittatus, D. vertebrates and males of B. cucurbitae.

\subsubsection{Buminal}

Buminal used on its own was much less effective than when it was associated with borax. It enabled us to capture primarily C. cosyra and sometimes C. fasciventris (Madina). Of 600 flies captured with buminal on its own, for all three sites together, the attractant was able to capture $85 \%$ females of C. cosyra and $70 \%$ females of C. fasciventris.

\subsubsection{Buminal associated with borax}

The mixture of buminal and borax was able to capture C. cosyra, C. silvestrii, C. quinaria and $C$. fasciventris. The acidity of the mixture, thanks to the borax, provided greater attraction than when using buminal on its own, and the capture results show that they were multiplied by a factor of between two and ten, depending on the sites studied. 
Though we obtained good results with the attractants used, it would be interesting to test the new liquid three-compound attractants (putrescine, trimethylamine and ammonium acetate), which are particularly effective with fruit fly females [21]. It could also be worthwhile experimenting with photosensitive substances, which have given inconsistent results in several countries [22], and which could replace insecticides in spot treatment.

\section{Tracking of evolution in percentage of attacks}

\subsection{Untreated plots with traps setup}

The damage to the main mango tree varieties other than Amélie was estimated for the three sites studied, and for several observation periods (tables III-VI).

On the Waibera site, the Kent variety proved to be the most attacked by Tephritidae holes during the first two observation periods, whereas, in the third and fourth weeks, it was the Brooks variety which was the most attacked by flies. On this site, the absence of damage to the Kent mango noted at the beginning of July can be explained by the fact that the harvest was over. The main fruit damage was observed, for the Keitt variety in particular, in the tree's lower layer, in the first two metres above the ground, in which shaded fruits surrounded with plenty of foliage proved to be particularly affected. The damage to Keitt and Brooks then fell regularly in July and August.

On the Madina site, the Keitt variety was more attractive than the Kent variety. This could be explained by an effect of the soil on the fruit coloration: unlike lateritic substrates, the sand-clay soil of this site does not promote bright coloration of fruits; the yellow Keitt mangos therefore apparently seem more attractive to fruit flies. But other factors could come into play. In the Madina orchards again, the holes especially affected fruits of the lower layer, particularly the Keitt fruits. The damage then decreased regularly in July and in August.

\section{Table III.}

Estimate of damage to the Kent variety mango tree attributable to Tephritidae (Mali, 2000 season, 300 fruits observed for each site studied and observation period).

\begin{tabular}{lccc} 
Observation period & $\begin{array}{c}\text { Waibera (Sikasso) } \\
\text { (\%) }\end{array}$ & $\begin{array}{c}\text { Madina (Bougouni) } \\
\text { (\%) }\end{array}$ & $\begin{array}{c}\text { Konyini (Bamako) } \\
\text { (\%) }\end{array}$ \\
\hline 12 to 15 June & 47.0 & 19.0 & 29.0 \\
19 to 22 June & 44.0 & 25.0 & 37.5 \\
26 to 29 June & 28.0 & 34.5 & - \\
03 to 06 July & - & 31.5 & - \\
10 to 13 July & - & 28.0 & - \\
17 to 20 July & - & 24.0 & - \\
24 to 27 July & - & 20.0 & - \\
31 July to 03 August & - & 14.0 & - \\
07 to 10 August & - & 16.8 & -
\end{tabular}

\section{Table IV.}

Estimate of damage to the Keitt variety mango tree attributable to Tephritidae (Mali, 2000 season, 300 fruits observed for each site studied and observation period).

\begin{tabular}{lccc} 
Observation period & $\begin{array}{c}\text { Waibera (Sikasso) } \\
\text { (\%) }\end{array}$ & $\begin{array}{c}\text { Madina (Bougouni) } \\
(\%)\end{array}$ & $\begin{array}{c}\text { Konyini (Bamako) } \\
\text { (\%) }\end{array}$ \\
\hline 12 to 15 June & 38 & 39 & 38 \\
19 to 22 June & 39 & 35 & 39 \\
26 to 29 June & 41 & 49.5 & 26 \\
03 to 06 July & 27.5 & 41 & - \\
10 to 13 July & 24.5 & 28.6 & - \\
17 to 20 July & 14.6 & 23.3 & - \\
24 to 27 July & 15 & 15.6 & - \\
31 July to 03 August & 10.3 & 9.3 & - \\
07 to 10 August & 8.3 & 10 & -
\end{tabular}

${ }^{1}$ On this site, the counts were made on 30 fruits from a single tree.

On the Konyini site, the Haden variety was the most affected. The high percentage of attacks noted on the Brooks variety mangos must be kept in perspective, since the counts were made on 30 fruits from a single tree.

In other untreated orchards visited in April, between 26\% (Bamako zone) and 61\% (Sikasso zone) damage was recorded to Amélie variety fruits.

Since our study started during April, it would be interesting to evaluate during 


\section{Table V.}

Estimate of damage to the Brooks variety mango tree attributable to Tephritidae (Mali, 2000 season, 300 fruits observed for each site studied and observation period).

\begin{tabular}{lccc} 
Observation period & $\begin{array}{c}\text { Waibera (Sikasso) } \\
(\%)\end{array}$ & $\begin{array}{c}\text { Madina (Bougouni) } \\
(\%)\end{array}$ & $\begin{array}{c}\text { Konyini (Bamako) } \\
(\%)\end{array}$ \\
\hline 12 to 15 June & 36.0 & - & 52.0 \\
19 to 22 June & 38.5 & - & 59.0 \\
26 to 29 June & 62.0 & - & 67.0 \\
03 to 06 July & 38.5 & - & - \\
10 to 13 July & 32.0 & - & - \\
17 to 20 July & 22.6 & - & - \\
24 to 27 July & 21.0 & - & - \\
31 July to 03 August & 15.3 & - & - \\
07 to 10 August & 14.0 & - &
\end{tabular}

Table VI.

Estimate of damage to the Haden variety mango tree attributable to Tephritidae (Mali, 2000 season, 300 fruits observed for each site studied and observation period).

\begin{tabular}{lccc} 
Observation period & $\begin{array}{c}\text { Waibera (Sikasso) } \\
(\%)\end{array}$ & $\begin{array}{c}\text { Madina (Bougouni) } \\
(\%)\end{array}$ & $\begin{array}{c}\text { Konyini (Bamako) } \\
(\%)\end{array}$ \\
\hline 12 to 15 June & - & - & 48 \\
19 to 22 June & - & - & 40 \\
26 to 29 June & - & - & 42
\end{tabular}

forthcoming studies the percentage of attacks on more precocious mangos than the export varieties observed. The fruits of other precocious varieties which we were unable to sample should also be studied, as well as the wild species' harvests such as Cordyla pinnata, Saba senegalensis, Sarcocephalus latifolius, Landolphia senegalensis, Ximenia americana and Annona senegalensis. Indeed, wild hosts are important complementary, replacement or continuity links for the development of a pest in a given biotope, and fruit flies are a good example.

\subsection{Spot treatments}

Since the trap counts showed that the economically damaging thresholds had been exceeded after the first weeks of observation, the spot treatments could be applied upon authorisation by the competent authorities.
Insecticide spray was applied to spots at the three sites, and at the same times. However, as we obtained similar results on these three sites, we chose to only report those obtained in Madina. This choice was based on the fact that this site was the biggest in terms of surface area (over 50 ha divided into two plots), the size of Tephritidae populations counted there (over $46 \%$ of the total flies captured in traps for the three sites) and yields recorded in 2000 (on average, $2 \mathrm{t} \cdot \mathrm{ha}^{-1}$ for Kent, $3 \mathrm{t} \cdot \mathrm{ha}^{-1}$ for Keitt).

In Madina (figure 2), a week after the first treatment (28 June), the results were modest, with the average number of $C$. cosyra captured per trap and per week dropping from 515 to 393. However, the second treatment ( 5 July) was more effective, since the average number of $C$. cosyra individuals captured per trap and per week dropped from 393 to 182 . The third treatment (12 July) did not give the anticipated results due to precipitation the day after the treatment, which washed out the spray applied. The fourth treatment ( 6 September) brought the damage to below the economically damaging threshold set at 25 flies per trap and per week, both for C. cosyra and for C. fasciventris, and the fifth (13 September) reinforced the rapid fall in populations of $C$ cosyra, and those of the other species. Since $C$. cosyra and $C$. fasciventris are two major pests, these results are encouraging.

The treatments carried out had an impact both on the number of flies captured and on the percentage damage recorded on the fruit. In fact, during the first week of July, the data available in Waibera and Madina pointed to a decrease in holes and captures, although there was a discrepancy between the population peak and the incidence of these holes.

Overall, comparison of the damage caused by the flies between the treated plots and the control plots was encouraging. In Madina, for example, damage to the Kent variety was two times greater for the control plot than for the treated plot (figure 3). The three treatments from the end of June to mid-July reduced the damage to the fruit considerably, while a slight increase in damage was perceivable during the second week of August, in the absence of treatment. 


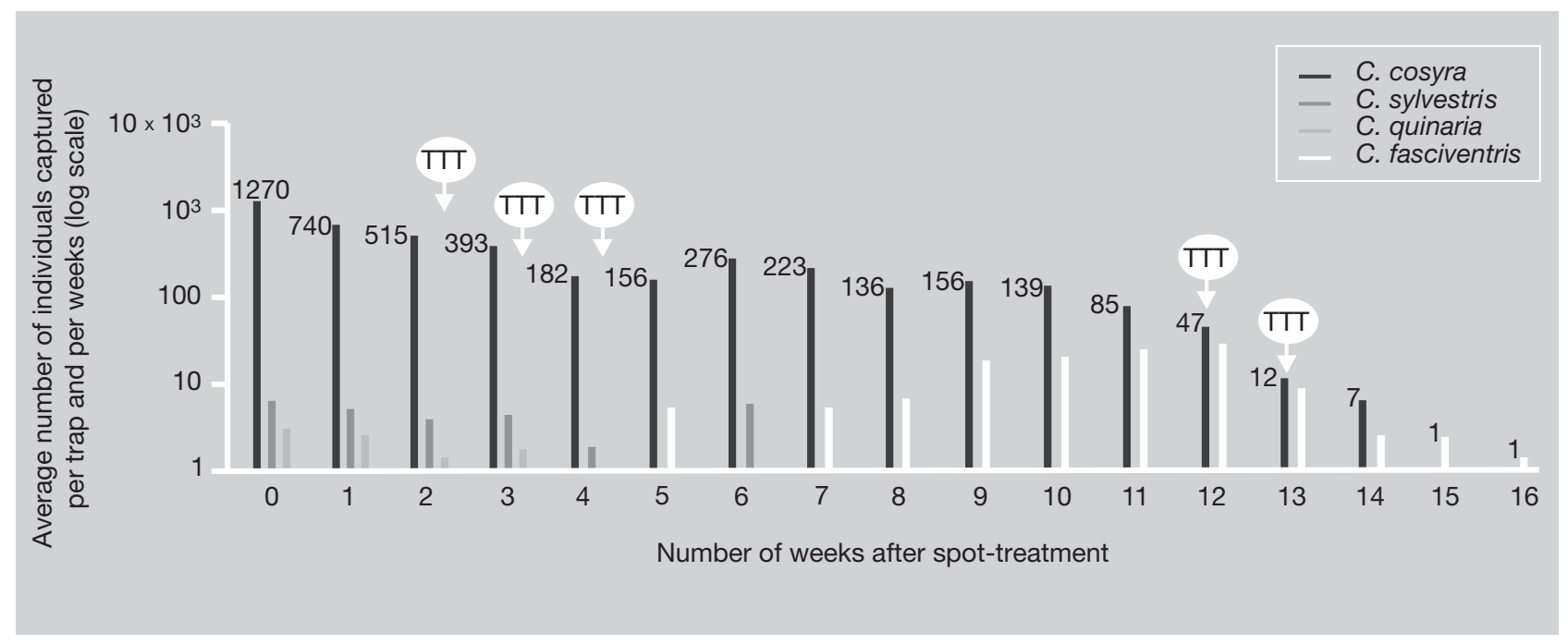

The comparison was even more marked for the Keitt variety (figure 4): at the end of July, only $10 \%$ damage was recorded to the crop of this late variety, which represented five times fewer fruit attacks than those observed one month before. While the impact of trapping was not zero, it was clear that the effect of the spot treatments was determining.

\section{Conclusion}

This research and development operation, undertaken under the aegis of the CAE (Centre Agro Entreprise) and with USAID funding (United States Agency for International Development) for control of mango Tephritidae in Mali, provided innovative results in scientific terms, interesting for applied research and promising for growers. The results obtained must be confirmed and expanded in the years to come.

Our trials enabled us to enrich in particular the bibliographical data on mango Tephritidae entomocoenosis, and on their natural control agents, since the inventory of species involved covered six species of primary mango pests, rather than the two previously listed. Thus, in light of our observations, the species C. anonae, C. quinaria, C. fasciventris and C. ditissima were found for the first time in Mali. Furthermore, over $80 \%$ of the larvo-pupal parasitoids (microhymenoptera) did not appear to have been reported before in Mali.
The damage evaluated from the observation of fruit samples taken was not as great on the exportable varieties (Kent and Keitt) as prior forecasts could have led us to assume. Nonetheless, the damage was very high, since we recorded over the 2000 season between $30 \%$ and $50 \%$ damage due to flies on the control plots.

The trapping system implemented gave excellent results, enabling us to recommend the generalised use of terpinyl acetate for detecting and evaluating populations of males of the main Tephritidae species of economic significance at the start of and during the season.

The spot treatment technique gave encouraging results, but the applications could not be tested under optimum conditions since
Figure 2.

Evolution in fruit fly captures obtained with terpinyl acetate traps (sex attractant) in mango orchards in Madina (Bougouni, Mali) during the 2000 season, as a function of the dates of the insecticide spot treatments applied.

\section{Figure 3.}

Fruit fly damage to Kent variety mangoes during the 2000 season, in the Madina trial orchards (Mali). Comparison between spot-treated zones and untreated control zones.

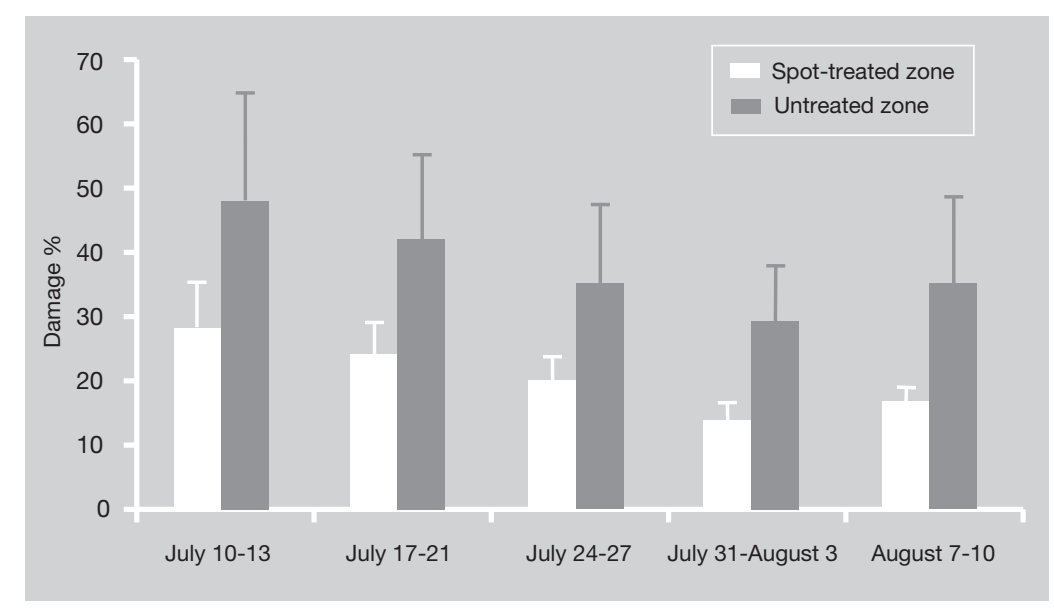




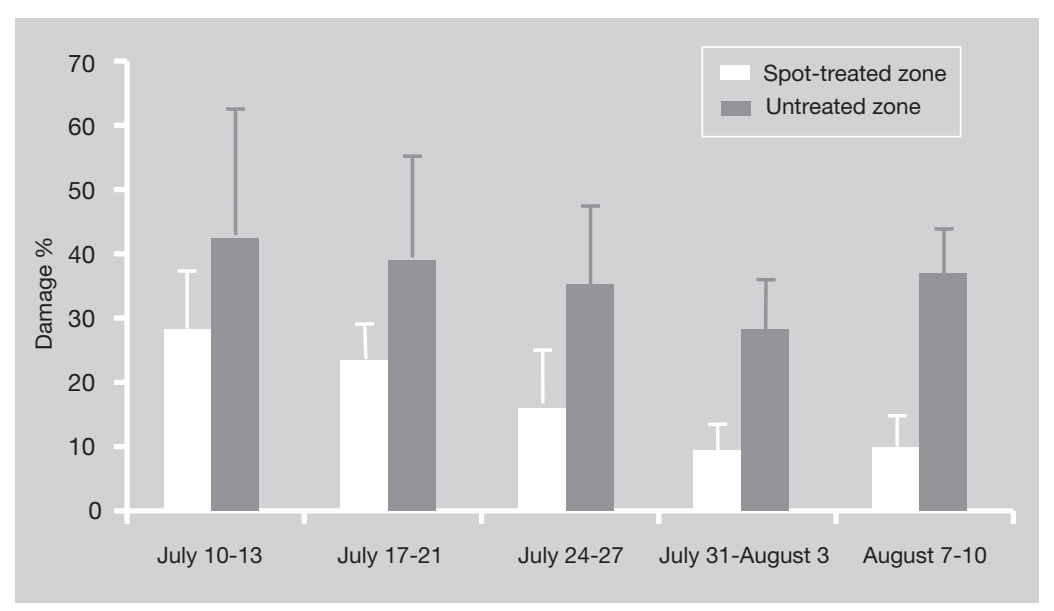

Figure 4.

Fruit fly damage to Keitt variety mangos during the 2000 season, in the Madina trial orchards (Mali). Comparison between spot-treated zones and untreated control zones. they were undertaken in the course of the season, rather than from the start of the season. The treatments must be repeated subsequently during the coming seasons and on other sites.

To continue the action undertaken, it would be interesting to create a regional mango tree Tephritidae control project for West Africa, which would extend to Mali, Senegal, Guinea, Burkina Faso and other countries which so desired. Drawing up a control strategy on this sub-regional scale actually appears fundamental in the medium term against these pests which are omnipresent in the sub-region.

\section{Acknowledgements}

We would like to extend our warmest thanks firstly to all the Malian planters who assisted us during this work, and in particular Mr. Soumaîla Diarra in Waibera, Mr. Fanto Traoré in Konyini and Mr. Bakary Ballo in Madina. We would also like to express our thanks to Mrs. Mémé Togola and Nangazana Koné (Rural Economics Institute, Sikasso) for their constant interest throughout our work, and to Mr. Moctar Boukenem, Mr. Geoffrey Livingstone and Mr. Andrew Lambert, for their general support in Mali. Our acknowledgements finally must go to Marc De Meyer for his precious assistance with the genus Ceratitis, and to Robert Wharton for his parasitoid identifications. We would also like to sincerely thank USAID for allowing us to publish these preliminary observations on mango fruit flies from Mali.

\section{References}

[1] N'Guetta K., Inventaire des insectes de fruits récoltés dans le Nord Côte d'Ivoire, Fruits 49 (1994) 502-503.

[2] Barbet A., Suivi des populations de cératites (Dipt. Tephritidae) en Nord Côte d'Ivoire dans la perspective d'une lutte raisonnée, Cnearc, mémoire, Montpellier, France, 2000, $52 \mathrm{p}$.

[3] Noussourou M., Diarra B., Lutte intégrée contre les mouches des fruits, Sahel IPM 6 (1995) 2-13.

[4] Vayssières J.F., Sangaré M., Enquête sur le potentiel de production de mangues en Haute-Guinée, Minist. Dév. Rural, Conakry, Guinée, 1995, 18 p.

[5] Vayssières J.F., Kalabane S., Inventory and fluctuations of the catches of Diptera Tephritidae associated with mangoes in Coastal Guinea, Fruits 55 (2000) 259-270.

[6] Anon., Mali : le secteur agropastoral domine, Marchés Tropicaux et Méditerranéens, Spécial Mali, 2842 (2000) 728-731.

[7] Coulibaly B., Évaluation du potentiel agricole de la filière mangue en $3^{\mathrm{e}}$ région, Mali Yiriden, Agence pour la promotion des filières agricoles, 1999, $66 \mathrm{p}$.

[8] Quilici S., Renforcement et stimulation de la lutte raisonnée contre les mouches des fruits, Cirad-Irfa, Rapp. Annu., Doc. Interne, Réunion, 1992, 8 p.

[9] Vincenot D., Synthèse de trois années d'expérimentation et de développement en lutte intégrée sur agrumes à l'île de la Réunion, Cirad-Flhor, doc. interne, Réunion, 1993, $36 \mathrm{p}$.

[10] De Meyer M., On the identity of the Natal fruit fly, Ceratitis rosa (Diptera Tephritidae), Bull. Inst. Res. Sci. Natl. Belg. Entomol. 71 (2001) 55-62.

[11] White I.M., Elson-Harris M., Fruit flies of economic significance: their identification and bionomics, Cab Int., Aciar, Redwood Press, Melksham, UK, 1992, 601 p.

[12] Nonveiller G., Catalogue des insectes du Cameroun d'intérêt agricole, Institut pour la protection des plantes, Mémoires XV, Belgrade, Yougoslavie, 1984.

[13] Hancock D.L., Ceratitinae (Diptera, Tephritidae) from the Malagasy subregion, J. Entomol. Soc. South Afr. 47 (1984) 277-301.

[14] Hancock D.L., Notes on some African Ceratitinae (Diptera Tephritidae) with special reference to the Zimbabwean fauna, Trans. Zimb. Sci. Assoc. 63 (1987) 47-57. 
[15] De Meyer M., Revision of the subgenus Ceratitis (Ceratalaspis) Hancock (Diptera Tephritidae), Bull. Entomol. Res. 88 (1998) 257-290.

[16] N'Guetta K., Rapport d'activité de recherche, Idefor-Dfa, Rapp. Interne, Côte d'Ivoire, 1998, 12 p.

[17] Silvestri F., Viaggio in Africa per cercare parassiti di mosche dei frutti, Boll. Lab. Zool. Gen. Agrar. Ric. Sci. Sup. Agric., Portici 8 (1913) 1-164.

[18] Etienne J., Étude systématique, faunistique et écologique des téphritidés de la Réunion, École pratique des hautes études, Thèse, Paris, France, 1982, $100 \mathrm{p}$.

[19] Vayssières J.F., Delvare G., Maldes J.M., Aberlenc H.P., Inventaire préliminaire des arthropodes ravageurs et auxiliaires des cultures maraîchères sur l'île de la Réunion, Insect Sci. Appl. 21 (2001) 1-22.
[20] Vayssières J.F., Carel Y., Les Dacini (Diptera Tephritidae) inféodées aux Cucurbitaceae à la Réunion : gamme de plantes hôtes et stades phénologiques préférentiels des fruits au moment de la piqûre pour des espèces cultivées, Ann. Soc. Entomol. Fr. 35 (1999) 197-202.

[21] Quilici S., Compte rendu de participation à la première réunion du programme coordonné FAO-AIEA " développement d'attractifs optimisés pour les mouches des fruits ", São Paulo, Brésil, 28/08/2000-01/09/2000, Cirad-Flhor, Rapp. interne, île de la Réunion, 2000.

[22] Liquido N.J., Mcquate G.T., Cunningham R.Y., Light-activated toxicity of phloxine $B$ and uranine to medfly, Ceratitis capitata (Wiedemann) adults, in: Light-activated pest control, chapter 7, Am. Chem. Soc., 1995, pp. 82-106.

\section{Inventario de las especies de moscas de la fruta (Diptera: Tephritidae) del mango en Malí y ensayos de control racional.}

Resumen - Introducción. En Malí, se estima en 100000 ha la producción anual de mangos. A consecuencia de problemas estructurales y fitosanitarios, principalmente relacionados con la acción de las moscas de la fruta, raramente se exporta más del 1\% de esta producción. El objetivo principal de este estudio consistió en poner a punto un método de control racional contra las moscas del mango en Malí mediante tratamientos zonales. Uno de los preliminares fue identificar las especies responsables de los daños en las tres áreas principales de producción (Sikasso, Bougouni, Bamako). Material y métodos. Se cosecharon mangos de las principales variedades exportadas entre principios de abril y principios de octubre de 2000; se pusieron en observación para identificar las especies de Tephritidae presentes en los frutos. La colocación de trampas con atrayentes sexuales o alimenticios permitió seguir la evolución y la constitución de las poblaciones de moscas de la fruta en las plantaciones frutales de los tres lugares elegidos. Se probó la eficacia de un método de tratamiento zonal para luchar contra ceratitis. Resultados y discusión. Basándose en observaciones y en la determinación de los adultos, se evidenciaron seis especies de Tephritidae. Dentro de éstas, Ceratitis cosyra (Walker), C. quinaria (Bezzi) y C. silvestrii Bezzi fueron las más precoces y, por tanto, las más dañinas. C. cosyra representó el 86\% del total de moscas atrapadas. Las especies C. anonae, C. quinaria, C. fasciventris y C. ditissima fueron identificadas por primera vez en Malí. Los daños causados por Tephritidae en campo alcanzaron el 50\% de la producción de las variedades Kent y Keitt y superó el 60\% en Brooks. Las 180 trampas colocadas en los tres sitios permitieron la captura de 128998 Tephritidae adultos pertenecientes a trece especies; las seis especies específicas del mango constituyen el 99\% del total capturado. Los tratamientos por zonas efectuados en los tres sitios experimentales arrojaron resultados alentadores, con una reducción de daños de aproximadamente el 50\% en las parcelas tratadas con respecto a los testigos. Conclusiones. Para incrementar el alcance de la acción iniciada, será interesante confirmar y profundizar en los resultados obtenidos durante los próximos años. La instauración de un proyecto regional de lucha contra las Tephritidae del mango en África Occidental sería fundamental, a medio plazo, para limitar las consecuencias de esta plaga que actúa a escala subregional.

Malí / Mangifera indica / Tephritidae / Ceratitis / identificación / daños / lucha integrada / trampas / dinámica de poblaciones 